\title{
Importin Subunit Beta-1
}

National Cancer Institute

\section{Source}

National Cancer Institute. Importin Subunit Beta-1. NCI Thesaurus. Code C142199.

Importin subunit beta-1 (876 aa, $\sim 97 \mathrm{kDa}$ ) is encoded by the human KPNB1 gene. This protein is involved in nuclear import. 